

\title{
PENGEMBANGAN PERANGKAT PEMBELAJARAN BERBASIS PENDEKATAN SAINTIFIK MODEL GUIDED DISCOVERY DAN EFEKTIVITASNYA TERHADAP PENGUASAAN KONSEP BIOLOGI SISWA SMA NEGERI 1 BAYAN
}

\author{
Raden Sumiadi ${ }^{1}$, Dwi Soelistya Dyah Djekti ${ }^{2}$, Jamaluddin ${ }^{3}$ \\ Magister Pendidikan IPA, Program Pascasarjana Universitas Mataram ${ }^{123}$ \\ Email: radensumiadi7@gmail.com
}

\begin{tabular}{|c|c|}
\hline Key Words & Abstract \\
\hline $\begin{array}{l}\text { Learning } \\
\text { device, } \\
\text { Scientific } \\
\text { approach, } \\
\text { Guided } \\
\text { discovery, } \\
\text { Mastery } \\
\text { of biological } \\
\text { concept }\end{array}$ & $\begin{array}{l}\text { The purposes of this research are 1) developing learning device based on scientific } \\
\text { approach with model of guided discovery 2) knowing elegibility peripheral of study base } \\
\text { on scientific approach model of guided discovery 3) Knowing effectiveness peripheral of } \\
\text { study to ability domination biological concept. Development peripheral of study use } \\
\text { model } 4 D \text { from Tiagrajan S. Semmel \& modified Semmel become three phase, that is } \\
\text { phase of define, design, and development. Result of development peripheral study is } \\
\text { hereinafter analysed to use formula of presentase adapted for mean the tables criterion } \\
\text { result of validasi. To know effectiveness peripheral of study to domination biological } \\
\text { concept, peripheral of study in aplicate limited group in SMAN } 1 \text { Bayan and analysed to } \\
\text { use formula of presentase complete individual. Result of research show, peripheral of } \\
\text { study base on scientific approach model of guided discovery categorized good (valid) } \\
\text { and very good (very valid) competent so that used in course study of biology in SMAN } 1 \\
\text { Bayan, and peripheral study can streamline ability of domination biological concept } \\
\text { student. }\end{array}$ \\
\hline Kata Kunci & Abstrak \\
\hline $\begin{array}{l}\text { Perangkat } \\
\text { Pembelajaran, } \\
\text { Pendekatan } \\
\text { Saintifik, } \\
\text { Guided } \\
\text { Discovery, } \\
\text { Penguasaan } \\
\text { Konsep Biologi }\end{array}$ & $\begin{array}{l}\text { Penelitian ini bertujuan untuk: 1) Mengembangkan perangkat pembelajaran berbasis } \\
\text { pendekatan saintifik dengan model guided discovery, 2) mengetahui kelayakan perangkat } \\
\text { pembelajaran berbasis pendekatan saintifik model guided discovery, 3) Mengetahui } \\
\text { efektivitas perangkat pembelajaran terhadap kemampuan penguasaan konsep biologi. } \\
\text { Pengembangan perangkat pembelajaran menggunakan model 4D dari Tiagrajan, S. } \\
\text { Semmel \& Semmel yang dimodifikasi menjadi tiga tahap, yaitu tahap define, design, dan } \\
\text { development. Hasil pengembangan perangkat pembelajaran selanjutnya dianalisis } \\
\text { menggunakan rumus presentase rata-rata yang disesuaikan dengan tabel kriteria hasil } \\
\text { validasi. Untuk mengetahui efektivitas perangkat pembelajaran terhadap penguasaan } \\
\text { konsep biologi, perangkat pembelajaran di ujicoba pada kelompok terbatas di SMA } \\
\text { Negeri } 1 \text { Bayan dan dianalisis menggunakan rumus presentase ketuntasan individu. Hasil } \\
\text { penelitian menunjukkan, perangkat pembelajaran berbasis pendekatan saintifik model } \\
\text { guided discovery dikategorikan baik dan sangat baik sehingga layak digunakan dalam } \\
\text { proses pembelajaran biologi di SMA Negeri } 1 \text { Bayan, dan perangkat pembelajaran dapat } \\
\text { mengefektifkan kemampuan penguasaan konsep biologi siswa }\end{array}$ \\
\hline
\end{tabular}




\section{PENDAHULUAN}

Pendidikan nasional memiliki tujuan makro yaitu membentuk manusia yang beriman dan bertaqwa kepada Tuhan Yang Maha Esa, memiliki etika, memiliki nalar, memiliki kemampuan komunikasi sosial, dan berbadan sehat sehingga menjadi manusia mandiri (Mulyasa, 2004). Untuk mencapai tujuan tersebut, pemerintah telah mengeluarkan berbagai kebijakan seperti; perbaikan sarana dan prasarana pendidikan, program sertifikasi guru, dan perubahan kurikulum. Namun demikian, upaya tersebut belum menunjukkan hasil yang memuaskan. Jika merujuk pada data kualitas pendidikan Indonesia yang dirilis oleh Programme for International Student Assessment (PISA) Tahun 2009 dan 2012 ternyata kemampuan literasi sains anak Indonesia masih rendah (Pratiwi, 2014).

Rendahnya kemampuan literasi sains siswa berkaitan erat dengan lemahnya proses pembelajaran IPA di kelas, guru belum mampu membuat dan melaksanakan perangkat pembelajaran yang dipadukan dengan pendekatan dan model pembelajaran yang dapat membimbing siswa belajar aktif, guru lebih cenderung menggunakan metode ceramah dalam mengajarkan konsep sehingga proses pembelajaran hanya berpusat pada guru, sedangkan siswa hanya diarahkan untuk menghafal konsep, fakta, dan teori. Dalam Proses pembelajaran IPA kususnya biologi, seharusnya guru dapat mendorong siswa untuk belajar aktif dengan menggunakan pendekatan dan model pembelajaran yang sesuai dengan karakteristik siswa. Oleh karena itu, sebelum mengajar guru harus mampu menjabarkan kompetensi dasar menjadi perangkat pembelajaran yang dapat mendorong siswa dalam mengembangkan kemampuannya.

Pendekatan saintifik merupakan pendekatan yang dapat membimbing siswa sebagai subyek belajar yang aktif melalui kegiatan ilmiah untuk membangun konsep, hukum, dan prinsip melalui tahap mengamati, menanya, mengumpulkan data, menalar, dan mengkomunikasikan data. Sawitri (2014) mengungkapkan bahwa proses pembelajaran menggunakan pendekatan saintifik dapat meningkatkan hasil belajar siswa SMA. Namun demikian, pendekatan saintifik masih bersifat umum jika digunakan dalam pembelajaran biologi di kelas, oleh karena itu dibutuhkan model pembelajaran yang tepat untuk memperkuat pendekatan pembelajaran tersebut. Salah satunya adalah model pembelajaran guided discovery.

Guided discovery merupakan model pembelajaran yang mengikuti pola kerja ilmiah yang dapat digunakan untuk membangun konsep di bawah bimbingan guru sehingga guru lebih kreatif dalam menciptakan situasi yang dapat membuat siswa belajar aktif menemukan pengetahuan sendiri (Sani, 2014). Model pembelajaran 
Guided discovery menekankan kreativitas belajar, siswa didorong untuk berpikir dan menganalisis sendiri sehingga dapat menemukan konsep berdasarkan data yang disediakan melalui kegiatan eksperimen dan eksplorasi buku. Pembelajaran Guided discovery merupakan model yang efektif digunakan dalam proses pembelajaran biologi karena dapat menuntun siswa dalam membangun konsep-konsep biologi yang tepat. Rahmawati et al. (2014) dalam penelitiannya mengungkapkan bahwa pembelajaran menggunakan model guided discovery dapat meningkatkan hasil belajar siswa. Merujuk dari hasil penelitian tersebut, pencapaian penguasaan konsep biologi siswa SMA Negeri 1 Bayan dapat dicapai jika guru mampu mengajarkan materi secara sistematis dengan pendekatan saintifik model pembelajaran guided discovery.

Berdasarkan hasil studi pendahuluan di SMA Negeri 1 Bayan terhadap kegiatan pembelajaran biologi, diperoleh informasi bahwa: 1) belum tersedianya perangkat pembelajaran yang dapat memfasilitasi siswa untuk belajar aktif, 2) guru belum mampu mengajar menggunakan pendekatan saintifik dengan model guided discovery, 3) masih banyak nilai siswa di bawah KKM.

Berdasarkan permasalahan di atas, tentu pembelajaran biologi di SMA Negeri 1 Bayan belum memenuhi tuntutan kurikulum 2013 yaitu pembelajaran yang berpusat pada siswa dengan menggunakan keterampilan proses sains. Berdasarkan hal itu, dipandang sangat perlu untuk melakukan penelitian "Pengembangan Perangkat Pembelajaran Berbasis Pendekatan Saintifik Model Guided Discovery dan Efektivitasnya terhadap Penguasaan Konsep Biologi Siswa SMAN 1 Bayan".

\section{METODE}

Penelitian ini merupakan penelitian dan pengembangan $(R \& D)$. Model yang digunakan untuk mengembangkan perangkat pembelajaran adalah model pengembangan Four D dari Thiagrajan \& Semmel (dalam Natsir, 2014). Sedangkan uji coba perangkat pembelajaran kelompok terbatas dilakukan di SMA Negeri 1 Bayan. Desain penelitian yang digunakan adalah two group pretestposttes (Sugiono, 2007). Sampel penelitian melibatkan dua kelas dengan jumlah 47 siswa. Kelas sampel dipilih berdasarkan pertimbangan peneliti (porpusive sampling).

Model Four D dalam penelitian terdiri dari empat tahap yaitu tahap define, design, develop, dan disseminate. Tahap define terdiri dari analisis masalah, analisis siswa, analisis tugas, analisis konsep, dan spesifikasi tujuan pembelajaran. Analisis masalah dilakukan dengan mengobservasi perangkat dan model pembelajaran yang sering digunakan oleh guru di SMAN 1 Bayan, observasi bahan pembelajaran siswa, studi literatur, dan penentuan materi pokok pembelajaran. Analisis siswa, dilakukan 
untuk mengetahui latar belakang siswa, pengetahuan awal siswa, dan pengalaman discovery siswa. Analisis tugas, dilakukan untuk merinci isi materi ajar dalam bentuk garis besar. Analisis ini mencakup analisis struktur isi, analisis prosedural, dan analisis proses informasi yang akan dituangkan dalam perangkat pembelajaran. Analisis konsep, merupakan identifikasi konsepkonsep utama yang menjadi target untuk dipahami oleh siswa. Spesifikasi tujuan pembelajaran, bertujuan untuk merumuskan tujuan pembelajaran berdasarkan indikator hasil belajar dalam kurikulum.

Tahap design meliputi penyusunan tes, pemilihan media, dan pemilihan format. Tujuan tahap ini adalah untuk menyiapkan tipe perangkat pembelajaran. Penyusunan tes sebagai penghubung antara tahap define dan tahap design. Tes disusun berdasarkan tujuan pembelajaran yang sudah dibuat. Pemilihan media yang sesuai untuk mencapai tujuan hasil pembelajaran. Pemilihan media akan disesuaikan dengan kondisi sekolah tempat akan diadakan penelitian. Media yang digunakan berupa alat dan bahan praktikum yang di laboratorium sekolah tersebut. Pemilihan format, kegiatan utama yang akan dilakukan pada tahap ini adalah merancang format perangkat pembelajaran yang akan dibuat.

Tahap develop, berupa validasi oleh Tim Ahli dan uji coba perangkat pembelajaran. Validator adalah tiga dosen ahli pendidikan. Secara umum aspek yang nilai adalah kelayakan isi, teknik penyajian, dan tata bahasa pada perangkat.

Efektivitas perangkat pembelajaran dapat diketahui dengan melakukan uji coba perangkat pembelajaran pada kelompok terbatas yaitu dengan melibatkan sampel 47 siswa. Desain penelitian yang digunakan adalah two group pretest-postest (Sugiono, 2007) sebagai berikut:

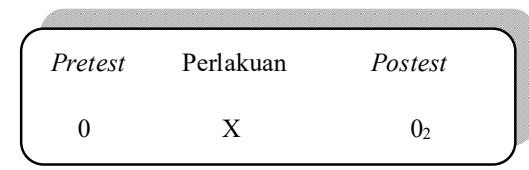

Untuk mengatahui hasil validasi dan tes penguasaan konsep biologi digunakan rumus sebagai berikut:

1) Menghitung rata-rata hasil validasi

$$
\mathrm{N}=\frac{\sum \text { skor setiap validator }}{\sum \text { skor maksimal }} \times 100 \%
$$

(Afian, 2014)

2) Menghitung penguasaan konsep biologi siswa digunakan rumus sebagai berikut:

Ketuntasan Individu $=\frac{\mathrm{TSe}}{\mathrm{TSh}} \times 100 \%$

Keterangan:

Tse $=$ total skor empirik yaitu nilai uji kompetensi yang dicapai

$\mathrm{TSh}=$ total skor maksimal yaitu nilai uji kompetensi maksimal (Akbar, 2013)

\section{HASIL DAN PEMBAHASAN}

Rekapitulasi hasil validasi tim ahli terhadap hasil pengembangan perangkat pembelajaran dapat dilihat pada Tabel 1 di bawah ini:

Tabel 1 Rekapitulasi skor hasil validasi 


\begin{tabular}{|c|l|c|l|}
\hline No & $\begin{array}{c}\text { Perangkat } \\
\text { Pembelajaran }\end{array}$ & $\begin{array}{c}\text { Nilai Rata- } \\
\text { Rata }\end{array}$ & Kategori \\
\hline 1 & Silabus & 3,5 & B \\
\hline 2 & RPP & 3,5 & B \\
\hline 3 & LKDS & 3,6 & SB \\
\hline 4 & BAS & 3,6 & SB \\
\hline 5 & TPK dan TBK & 3,8 & SB \\
\hline
\end{tabular}

Keterangan

$\begin{array}{ll}\mathrm{SB} & =\text { Sangat baik } \\ \mathrm{B} & =\text { Baik }\end{array}$

Tes penguasaan konsep siswa, dihimpun dalam bentuk gambar hasil penguasaan konsep biologi berikut ini:

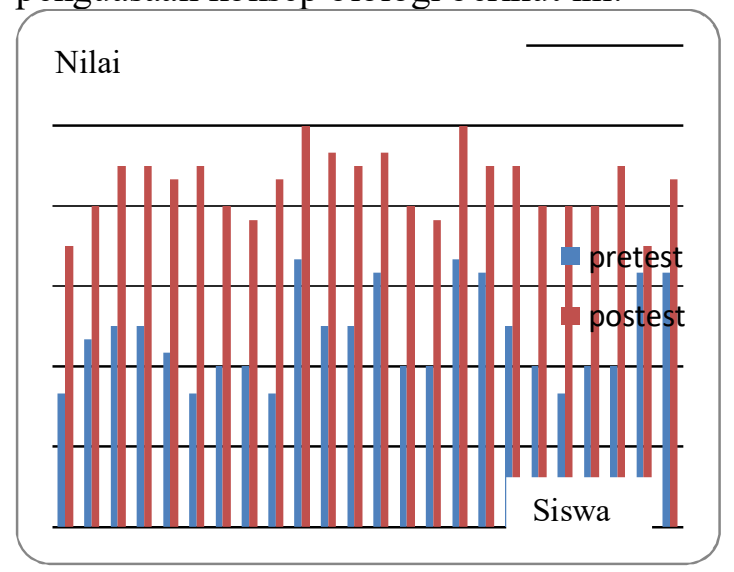

Gambar 1 Skor penguasaan konsep kelas XI IPA1



Gambar 2 Skor penguasaan konsep kelas XI IPA 2

Perangkat pembelajaran biologi yang dikembangkan peneliti pada penelitian ini sesuai dengan tuntutan kurikulum 2013 yaitu menggunakan pendekatan saintifik model guided discovery. Sedangkan guru mata pelajaran mengembangkan perangkat pembelajaran menekankan pada metode ceramah. Perangkat pembelajaran yang dimaksud berupa Silabus, rencana pelaksanaan pembelajaran (RPP), lembar kegiatan discovery siswa (LKDS), buku ajar siswa (BAS), Tes Penguasaan Konsep (TPK), dan Tes Berpikir Kreatif (TBK).

Tahapan pendekatan saintifik dengan menggunakan model guided discovery tergambar pada Silabus, RPP, LKDS, dan Buku Ajar Siswa. Perangkat pembelajaran yang telah dikembangkan oleh peneliti selanjutnya di validasi oleh tiga orang validator.

Berdasarkan nilai validasi yang diberikan oleh validator terhadap perangkat pembelajaran, diperoleh rata-rata nilai dengan kategori baik dan sangat baik seperti yang terlihat pada Tabel 1. Ini menunjukkan bahwa semua perangkat pembelajaran yang dikembangkan oleh peneliti layak dan dapat digunakan. Proses pengembangan perangkat pembelajaran ini didukung oleh penelitian Putrawan (2014) bahwa hasil pengembangan perangkat pembelajaran dengan pendekatan saintifik diperoleh kategori baik, layak, dan efektif

Silabus yang dikembangkan peneliti memiliki karakteristik dapat mencerminkan indikator yang dapat mencapai kompetensi dasar, kegiatan pembelajaran menekankan aktivitas siswa dengan menggunakan pendekatan saintifik model guided discovery learning. Silabus yang dikembangkan oleh guru mata pelajaran biologi di sekolah lebih 
menekankan pada aktivitas guru, alokasi waktu tidak dijabarkan pada masing-masing indikator. Silabus tersebut selanjutnya divalidasi dan digunakan sebagai acuan untuk mengembangkan rencana pelaksanaan pembelajaran. Berdasarkan analisis hasil validasi yang diberikan oleh validator terhadap silabus menunjukkan kriteria nilai masing-masing aspek pada silabus relatif sama yaitu baik dan sangat baik. Kriteria nilai diperoleh dengan rata-rata semua aspek adalah 3,5. Hal ini menunjukkan silabus yang dikembangkan peneliti berada pada kategori baik sehingga layak digunakan guru dalam mengembangkan RPP dan perangkat pembelajaran lainnya.

Rencana Pelaksanaan Pembelajaran (RPP) yang dikembangkan oleh guru mata pelajaran biologi lebih menekankan pada aktivitas guru karena menggunakan metode ceramah, kegiatan inti tidak menunjukkan adanya usaha guru dalam membimbing siswa menemukan konsep. Sedangkan RPP yang dikembangkan oleh peneliti lebih menekankan pada aktivitas siswa dalam menemukan konsep yaitu menggunakan pendekatan saintifik dengan model guided discovery. Berdasarkan hasil analisis nilai yang diberikan oleh validator, hasil yang diperoleh relatif sama yaitu kategori baik dan sangat baik. Jika ditinjau dari nilai semua aspek, nilai rata-rata diperoleh dari RPP yang telah dikembangkan adalah 3,5. Hal ini menunjukkan bahwa RPP yang telah dikembangkan berada pada kategori baik sehingga perlu sedikit perbaikan sesuai dengan saran dari ketiga validator.

LKDS yang dikembangkan berbasis pendekatan saintifik model guided discovery berisi pertanyaan-pertanyan yang dapat membimbing siswa dalam melakukan kegiatan penyelidikan sehingga dapat mendorong terjadinya interaksi aktif antara siswa dengan sumber belajar. LKDS yang dikembangkan berbeda dengan LKDS yang dikembangkan oleh guru mata pelajaran biologi, karena LKDS yang digunakan oleh guru merupakan buatan penerbit sehingga tidak relevan dengan karakteristik siswa. Hasil validasi LKDS diperoleh kriteria sangat baik. Jika nilai semua aspek di analisis, diperoleh hasil 3,6. Hal ini menunjukkan bahwa LKDS yang telah dikembangkan berada pada kategori sangat baik.

Buku ajar siswa dikembangkan untuk memudahkan siswa dalam menemukan konsep. Buku ajar siswa disusun berdasarkan pendekatan saintifik model guided discoveri, sehingga didalamnya terdapat pertanyaan yang dapat mendorong siswa untuk berdiskusi secara kelompok. Berdasarkan hasil validasi buku ajar siswa yang diberikan oleh tiga orang validator, diperoleh informasi bahwa buku ajar siswa memiliki kategori sangat baik dengan nilai rata-rata 3,6 . 
Hasil uji coba perangkat pembelajaran pada kelompok terbatas menunjukkan hasil tes menggunakan delapan soal uraian diperoleh perbedaan yang signifikan antara nilai pretest dan postest. Kelas IPA 1 memperoleh nilai pretest dengan nilai tertinggi 66,6 dan terendah 33,3. Jika dianalisis nilai rata-rata pretest seluruh siswa kelas IPA 1 adalah 44,8 sehingga dikategorikan nilai pretest yang diperoleh belum tuntas karena di bawah KKM. Sebaliknya pada saat postest dilaksanakan yaitu setelah kegiatan pembelajaran menggunakan pendekatan saintifik model guided discovery, nilai siswa meningkat dengan capaian nilai tertinggi 100 dan terendah 70. Sejumlah 22 siswa memperoleh nilai tuntas dengan prosentase 91,7\%. Ketuntasan siswa tersebut disebabkan motivasi anak dalam belajar karena merasa dilibatkan secara langsung dalam pembelajaran dan didukung juga dengan media seperti tayangan slide menggunakan leptop dan LCD sehingga diskusi dapat berjalan dengan baik. Hanya ada 2 siswa memperoleh nilai tidak tuntas yaitu 70 , sehingga presentase siswa yang tidak tuntas adalah 8,3\%. Walaupun nilai keduanya belum tuntas, namun nilai yang diperoleh tersebut mengalami peningkatan jika dibandingkan dengan perolehan nilai pretest. Beberapa faktor yang menyebabkan belum tuntasnya kedua anak tersebut adalah kurang aktif dalam berdiskusi dengan anggota kelompok. Akan tetapi, secara umum sebagian besar siswa di kelas IPA 1 telah tuntas dengan nilai rata-rata 85,4 dan nilai ketuntasan klasikal 91,6\%.

Sebaran nilai yang diperoleh siswa di kelas XI IPA 1 tidak jauh berbeda dengan perolehan nilai siswa di kelas XI IPA 2 pada saat diberikan pretest dan postest. Nilai penguasaan konsep biologi siswa kelas IPA 2 setelah pretest berada di bawah nilai KKM dengan nilai tertinggi 66,6 dan terendah 33,3. Nilai rata- rata pretest siswa di kelas XI IPA 2 yaitu 49,11 dengan kategori belum tuntas. Sebaliknya nilai postest siswa setelah belajar menggunakan pendekatan saintifik dengan model pembelajaran guided discovery, mengalami peningkatan dengan nilai tertinggi 100 dan nilai terendah 73,3 dengan nilai rata-rata 85,7. Sejumlah 21 siswa telah tuntas memperoleh nilai diatas KKM (75) dengan presentase ketuntasan klasikal 91,3\%. Walaupun nilai anak tesebut belum tuntas namun mengalami peningkatan jika dibandingkan dengan nilai pretest. Secara umum sebagian besar siswa di kelas XI IPA 2 telah tuntas.

Berdasarkan deskripsi data hasil tes penguasaan konsep di atas, diketahui bahwa pembelajaran dengan menggunakan pendekatan saintifik model guided discovery dapat mengefektifkan penguasaan konsep biologi siswa. Hal ini menunjukkan bahwa hasil penelitian ini relevan dengan hasil penelitian sebelumnya yang telah dilakukan 
oleh Widiadnyana et al. (2014) bahwa pembelajaran menggunakan model guided discovery berpengaruh positif terhadap penguasaan konsep IPA dasn sikap ilmiah siswa SMP, Yuniarti et al. (2014) pembelajaran dengan model guided discovery dengan pendekatan saintifik dapat meningkatkan pemahaman materi siswa.

\section{PENUTUP}

Berdasarkan hasil dan pembahasan di atas dapat disimpulkan hasil bahwa (1) hasil validasi ahli terhadap hasil pengembangan perangkat pembelajaran adalah diperoleh kategori baik dan sangat baik sehingga layak digunakan dalam pembelajaran biologi di SMA, (2) perangkat pembelajaran efektif dapat meningkatkan hasil belajar siswa SMAN 1 Bayan.

Kepada para pembaca yang ingin melakukan penelitian yang sejenis, maka disarankan untuk melakukan penelitian lanjutan dengan melakukan uji coba produk pada kelompok yang lebih luas yaitu melibatkan lebih dari satu sekolah.

\section{DAFTAR PUSTAKA}

Afian, T. 2014. Pengembangan Perangkat Pembelajaran Sains Berorientasi Guided Discovery Untuk Mengajarkan Kemampuan Berpikir Kreatif dan Penguasaan Konsep. Tesis: Universitas Negeri Surabaya.

Akbar, S. 2013. Instrumen Perangkat Pembelajaran. Bandung: Remaja Rosdakarya
Eggen, P \& Kauchak, D. 2012. Strattegi and Models for Teachers Taeching Content and Thingking Skills. Canada: University of North Florida.

Mulyasa. 2004. Kurikulum Berbasis Kompetensi Konsep, Karakteristik, dan Implementasi. Bandung: Remaja Rosdakarya.

Pratiwi, A.F. 2014. Pengaruh Penggunaan Model Discovery Learning dengan Pendekatan Saintifik Terhadap Keterampilan Berpikir Kritis Siswa SMA. Diunduh dari http://www.ejournal.ac.id.unesa/artic le, diakses tanggal 7 Januari 2015.

Rahmawati, Y., Mardiana, dan Subanti, S. 2014. Pengembangan Perangkat Pembelajaran Berbasis Penemuan Terbimbing (guided discovery) dengan Pendekatan Somatic, Auditory, Visual, Intellectual (savi) pada Materi Pokok Peluang Kelas IX SMP. Jurnal Elektronik Pembelajaran Matematika: Volume 2. No 4. Halaaman 379-388: Diunduh dari http://journal.fkip.uns.ac.id tanggal 7 Januari 2015.

Sani, A.R. 2014. Pembelajaran Saintifik untuk Implementasi Kurikulum 2013. Jakarta: PT Bumi Aksara.

Sawitri, W.D. 2014. Pengembangan Modul Keanekaragaman Hayati berbasis Pendekatan Saintifik untuk Kelas X SMA. Jurnal Bioedu Berkala Ilmiah Pendidikan Biologi: Volume 3.

Siswono, E.Y.T. 2005. Upaya Meningkatkan Kemampuan Berpikir Kreatif Siswa melalui Pengajuan Masalah. Jurnal Pendidikan Matematika dan Sains: Volume 3. No 1. Halaman 1-9: Diunduh dari http://jupms.ac.id/php Tanggal 4 Januari 2015. 
Sugiono, 2007. Metode Penelitian Kuantitatif, Kualitatif dan $R \& D$. Bandung: $\quad$ Alfabeta.

Wayan, A., Wayan, L dan Marhaeni. 2013. Pengaruh Model Sains-TeknologiMasyarakat (STM) terhadap Kemampuan Berpikir Kreatif dan Pemahaman Konsep dalam Pembelajaran IPS Siswa SD di Desa Kalibukbuk. e-Journal Program Pascasarjana Universitas Pendidikan Ganesha Jurusan Pendidikan Dasar: Volume 3. No 1. Hal 43-48: Duinduh dari http://www pasca.undiksha.ac.id/php Tanggal 8 Januari 2015.

Widiyatyana, W.,Sadia, W.,Suastra, W. 2014. Pengaruh Model Discovery Learning terhadap Pemahaman Konsep IPA dan Sikap Ilmiah Siswa SMP. e-Journal Program Pascasarjana Universitas Pendidikan Ganesha Jurusan Pendidikan Dasar: Volume 4. No 1. Hal 43-48: Duinduh dari http://www pasca.undiksha.ac.id/php Tanggal 7 Januari 2015.

Yuniarti, T.,Subanti, S.,Riyadi. 2014. Pengembangan Perangkat Pembelajaran Berbasis Masalah (problem based learning) dengan Pendekatan Ilmiah (scientific Approach) pada Materi Segitiga Kelas VII SMP Se-Kabupaten Karang Anyar Tahun Pelajaran 2013/2014. Diunduh dari http://www upeca.ac.is/php tanggal 5 Januari 2015. 